\title{
ANALISIS KESALAHAN SISWA DALAM MENYELESAIKAN PERMASALAHAN INTEGRAL TAK TENTU
}

\author{
Siti Nurhikmah' ${ }^{1} \&$ Febrian$^{2}$ \\ ${ }^{12}$ Universitas Maritim Raja Ali Haji, Kepulauan Riau, Indonesia \\ ${ }^{1}$ snurhikmah.sn@gmail.com, ${ }^{2}$ febrianfebz@gmail.com
}

\begin{abstract}
Abstrak
Dalam studi ini, penulis melakukan analisis kesalahan siswa dalam menjawab soal-soal tes pada topik integral tak tentu dengan metode subsitusi. Tujuan dilakukan studi ini, yaitu (1) untuk mengetahui tipetipe kesalahan yang dilakukan siswa dalam menyelesaikan soal tes pada topik integral tak tentu, (2) untuk mengetahui persentase tiap tipe kesalahan siswa perbutir soal pada topik integral tak tentu, dan (3) untuk mengetahui kesalahan dominan siswa secara keseluruhan pada topik integral tak tentu. Subjek dalam penelitian ini adalah 30 siswa kelas XI.IPA.1 SMA Negeri 2 Tanjungpinang yang berlokasi di jalan Basuki Rachmat Tanjungpinang. Studi ini dilakukan dengan memberikan lembar soal yang disusun melalui tahap diskusi dan validasi berupa soal essay sebanyak 16 butir soal yang terbagi menjadi dua paket yang masing-masing paket berisikan delapan butir soal. Berdasarkan hasil analisis data diperoleh persentase dominan kesalahan siswa secara keseluruhan berdasarkan kategori kesalahan menurut Watson, yaitu data tidak tepat sebesar $25 \%$, prosedur tidak tepat sebesar 20,83\%, data hilang sebesar 18,75\%, kesimpulan hilang sebesar 9,72\%, konflik level respon sebesar 0,69\%, manipulasi tidak langsung sebesar 15,28\%, masalah hierarki keterampilan sebesar 9,72\%, dan selain dari ketujuh kategori kesalahan diatas sebesar 0\%. Hasil dari analisis menunjukkan bahwa kesalahan dominan yang dilakukan siswa yaitu kesalahan data tidak tepat.
\end{abstract}

Kata Kunci: Analisis Kesalahan Siswa, Kategori Kesalahan Menurut Watson, Integral Tak Tentu

Abstract
This study displays an error analysis conducted on students' answers
towards the questions within the test on the topic of indefinite integral
by using substitution method. This study aims at (1) analyzing error
types undertaken by the students during accomplishing the questions,
(2) deriving the percentage of each error type on the behalf of existing
errors comparison, and (3) identifying the dominant error(s) for whole
cases on the topic of indefinite integral by using substitution method to
enable conclusion and reflection at the end of the study. The subject of
the research is thirty students of 12 nd graders of Science 1 of SMA Negeri
2 Tanjungpinang located in Basuki Rahmat Street, Tanjungpinang. This
study is conducted by distributing sheets containing questions designed
through the discussion and validation phases. The questions are in form
of essay and there are 16 of them distributed into two groups of sheets
(each group consists of eight questions). Based on the result of analysis
by using Watson students' error categorization, it is obtained that
dominant percentage for error existing is $25 \%$ for inappropriate data.
Others are 20.83\% for inappropriate procedure, $18.75 \%$ for omitted
data, $9.72 \%$ for omitted conclusion, $0.69 \%$ for response level conflict,


$15.28 \%$ for undirected manipulation, $9.72 \%$ for skills hierarchy problem, and $0 \%$ for possible others found. This result concludes that the most frequent error existing is inappropriate data.

Keywords: Students' Error Analysis, Watson's Error Categorization, Indefinite Integral

\section{PENDAHULUAN}

Matematika adalah salah satu bidang studi yang memiliki peran penting dalam pendidikan. Hal ini dapat dilihat dan dibuktikan pada jam pelajarannya yang lebih banyak dibandingkan pelajaran yang lainnya, serta bidang studi matematika dipelajari oleh seluruh tingkatan pendidikan seperti SD, SMP/MTS, dan SMA/sederajat. Matematika penting baik sebagai alat bantu, sebagi ilmu, maupun pembentuk sikap dan pembimbing pola piker (Fathani, 2009). Meskipun demikian, matematika masih dianggap pelajaran yang sulit, menakutkan dan membuat siswa enggan mempelajarinya.

Penerapan pembelajaran matematika biasanya lebih menekankan siswa pada teknik menghafal definisi maupun rumus matematika. Kesalahan yang sering dilakukan siswa dalam mengerjakan soal matematika yaitu mengerjakan soal matematika dengan cara menghafal dan tidak disertai dengan latihan (Istiyanto dalam Uni, 2009). Padahal dalam mempelajari matematika siswa harus ditekankan pada pemahaman, penalaran dan pengaplikasian soal dalam menyelesaikan suatu masalah agar siswa dapat berpikir kritis, logis cermat, terstruktur, dan efektif (Depdiknas, 2004). Proses pembelajaran siswa yang cenderung lebih kepada menghafal tidak sepenuhnya berhasil dalam mewujudkan prestasi belajar siswa yang baik. Untuk mengetahui tercapai atau tidaknya tujuan pembelajaran matematika dapat dinilai dari keberhasilan siswa dalam memahami konsep matematika dan mengaplikasikan pemahaman tersebut dalam menyelesaikan suatu permasalahan yang diberikan dan dapat diaplikasikan dalam kehidupan sehari-hari. Untuk itu, diperlukan suatu tes atau ujian untuk mengetahui kemampuan yang dimiliki siswa serta kesalahan siswa dalam menjawab soal. 
Nurhikmah, S., \& Febrian, F. (2016). ANALISIS KESALAHAN SISWA DALAM MENYELESAIKAN PERMASALAHAN INTEGRAL TAK TENTU. JURNAL TATSQIF, 14(2). Retrieved from http://ejurnal.iainmataram.ac.id/index.php/tatsqif/article/view/1074

Pemberian tes berguna untuk mengevaluasi hasil belajar siswa. Evaluasi bertujuan untuk mengukur sejauh mana pemahaman siswa terhadap materi yang telah diajarkan. Depdikbud dalam Arikunto (2012) mengemukakan "evaluasi adalah suatu kegiatan untuk memberikan berbagai informasi secara berkesinambungan dan menyeluruh tentang proses dan hasil yang telah dicapai siswa".

Sebagai calon guru matematika, perlu adanya persiapan tentang bagaimana seorang guru harus peka terhadap sejauh mana pemahaman siswa dari yang telah diajarkan. Demikian juga, perlunya kepedulian seorang guru matematika dalam memperhatikan setiap kesalahan - kesalahan siswa dalam menyelesaikan permasalahan dengan menggunakan konsep yang telah diajarkan. Hal ini berguna sebagai tolak ukur sistem dan memilih cara mengajar yang baik pada konsep selanjutnya. Berhasil tidaknya seorang guru bukan hanya terletak pada sejauh mana siswa takut dan mau mendengarkan arahan, namun bagaimana seorang guru mampu membuat siswa benarbenar paham tentang materi yang diajarkan.

Dalam pemberian soal tes guru juga harus memperhatikan bentuk tes yang diberikan agar tes tersebut sesuai dengan tujuan pembelajaran yang ingin dicapai. Tes adalah suatu cara untuk mengadakan penilaian suatu tugas atau serangkaian tugas yang harus dikerjakan oleh siswa atau sekelompok siswa sehingga menghasilkan suatu nilai tentang tingkah laku atau prestasi siswa tersebut, dalam pembelajaran matematika tes yang sesuai untuk digunakan yaitu tes uraian (essay), karena tes essay menuntut baik pengajar maupun pelajar untuk bernalar dan mengungkapkan sejauh mana kemampuan yang dimiliki (Nurkencana, 1993). Sebagaimana didefinisikan, tes uraian adalah kebebasan menjawab pertanyaan yang ditujukan kepada seseorang, yang menuntutnya agar memberikan jawaban sendiri, relatif bebas, bagaimana mendekati masalahnya, informasi apa yang akan digunakan, bagaimana mengorganisasi jawabannya, dan berapa besar tekanan yang diberikan kepada setiap aspek jawaban (Nitko, 1996). Sehingga 
Nurhikmah, S., \& Febrian, F. (2016). ANALISIS KESALAHAN SISWA DALAM MENYELESAIKAN PERMASALAHAN INTEGRAL TAK TENTU. JURNAL TATSQIF, 14(2). Retrieved from http://ejurnal.iainmataram.ac.id/index.php/tatsqif/article/view/1074

hal tersebut sangat membantu guru untuk mengetahui sejauh mana pengetahuan siswa terhadap soal yang diberikan dengan pengetahuan dan wawasan yang siswa miliki.

Pada dasarnya setiap siswa memiliki pemahaman yang berbeda-beda sehingga menghasilkan hasil tes yang berbeda. Ketidakpahaman siswa tentang materi yang telah diajarkan menjadi sebab utama terjadinya kesalahan-kesalahan yang tidak diinginkan. Dari pengujian beberapa soal, dapat dilihat bagian mana ketidakpahaman siswa terhadap integral tak tentu dengan menggunakan metode subsitusi ataupun apakah benar struktur penyelesaiannya dan sebagainya.

Menurut Watson dalam Sunardi (1995) kategori kesalahan-kesalahan yang sering terjadi pada siswa, yaitu:

a. Data tidak tepat (inappropriate data/id)

Dalam kasus ini siswa berusaha mengoperasikan pada level yang tepat pada suatu masalah, tapi memilih sebuah informasi yang tidak tepat seperti salah memasukkan data dalam variabel.

Contoh kasus dalam topik integral tak tentu mengenai data tidak tepat yaitu siswa biasanya salah memasukkan (mensubstitusi) data dalam variabel dikarenakan siswa kurang teliti dan terburu-buru dalam menjawab soal.

b. Prosedur tidak tepat (inappropriate procedure/ip)

Dalam kasus ini siswa berusaha mengoperasikan masalah pada level yang tepat, tetapi prosedur yang digunakan tidak tepat. Contohnya adalah kurang tepat dalam menggunakan rumus, tidak sesuai dengan kaidah yang berlaku dalam matematika.

c. Data hilang (omitted data/od)

Dalam kasus ini adanya data yang hilang pada jawaban siswa. Sehingga penyelesaian menjadi tidak benar, namun masih berusaha mengoperasikan pada level yang tepat. 
Data hilang umumnya terjadi dikarenakan siswa kurang teliti dalam menjawab soal, sehingga adanya data yang hilang serta urutan penyelesaian yang tidak sinkron dengan proses yang lainnya.

d. Kesimpulan hilang (omitted conclusion/oc)

Dalam kasus ini siswa mengoperasikan pada level yang tepat namun gagal dalam menyimpulkan. Hal ini karena, kurangnya pemahaman siswa terhadap pertanyaan yang ada dalam soal dan tidak tuntasnya proses penyelesaian soal.

Contoh pada penyelesaian soal tes integral tak tentu, sering ditemukan siswa yang pada awalnya memisalkan suatu fungsi dengan u setelah diintegralkan siswa tidak mengubah kembali permisalan tadi dengan fungsi awalnya, sehingga tidak ditemukan hasil akhir yang diharapkan.

e. Konflik level respon (response level conflict/rlc)

Dalam kasus ini siswa menunjukkan satu kompetisi operasi pada level tertentu kemudian menurunkan ke operasi yang lebih rendah, biasanya untuk kesimpulan.

Sebagai contoh seorang siswa yang masih belum memahami soal pada topik integral tak tentu sepenuhnya, karena masih ragu dalam teknik penyelesaian sehingga untuk mendapatkan nilai yang benar, siswa melakukan dua cara penyelesaian dengan hasil yang berbeda.

f. Manipulasi tidak langsung (undirected manipulation/um)

Dalam kasus ini siswa membuat alasan yang diperoleh dengan menggunakan alasan yang sederhana dan reasoning yang tidak logis atau acak.

Contohnya sebuah penyelesaian harus memperhatikan aturan-aturan, permisalan dan sebagainya, tetapi penyelesaian yang siswa gunakan justru tidak sesuai dengan aturan yang berlaku.

g. Masalah hierarki keterampilan (skills hierarchy problem/shp)

Dalam kasus ini, siswa kurang teliti dalam melakukan keterampilan menghitung, salah operasi dan lain-lain. Penyebab kesalahan yang pada 
umumnya dilakukan oleh siswa yaitu tidak teliti dan terburu-buru dalam mengerjakan soal sehingga berdampak pada kesalahan siswa yaitu eror kalkulasi atau salah menghitung sehingga menghasilkan hasil akhir yang salah.

h. Selain dari tujuh kategori di atas

Kasus kesalahan-kesalahan siswa dalam menyelesaikan soal yang tidak termasuk pada ketujuh kategori di atas dikelompokkan dalam kategori ini.

Studi ini memuat analisa kesalahan yang mungkin muncul ketika siswa memberikan jawaban tertulis dalam mengerjakan tes pada topic Integral tak tentu dengan Metode Subtitusi. Tujuan dilakukannya analisis kesalahan siswa ini adalah:

1. Untuk mengetahui kesalahan-kesalahan yang sering terjadi pada siswa dalam menyelesaikan soal tentang topik integral tak tentu.

2. Untuk membantu guru agar mengetahui pemahaman siswa pada topik integral tak tentu.

3. Untuk mengevaluasi sejauh mana pemahaman siswa terhadap topik integral tak tentu yang telah diajarkan guru.

4. Sebagai tolak ukur penulis dalam menerapkan model dan metode pembelajaran yang tepat sebagai calon guru matematika agar tidak terjadinya hal-hal yang tidak diinginkan dalam pembelajaran.

Berdasarkan uraian di atas, maka dapat dirumuskan permasalahan sebagai berikut:

1. Apa saja jenis kesalahan siswa dalam menyelesaikan soal pada topik integral tak tentu metode subsitusi berdasarkan kategori kesalahan menurut Watson?

2. Berapa persentase dominan kesalahan siswa dalam menyelesaikan soal tes pada topik integral tak tentu dengan metode subsitusi berdasarkan kategori kesalahan menurut Watson? 
Nurhikmah, S., \& Febrian, F. (2016). ANALISIS KESALAHAN SISWA DALAM MENYELESAIKAN PERMASALAHAN INTEGRAL TAK TENTU. JURNAL TATSQIF, 14(2). Retrieved from http://ejurnal.iainmataram.ac.id/index.php/tatsqif/article/view/1074

3. Berapa persentase dominan kesalahan siswa secara keseluruhan soal tes dalam menyelesaikan soal pada topik integral tak tentu dengan metode subsitusi berdasarkan kategori kesalahan menurut Watson?

\section{METODE PENELITIAN}

Jenis penelitian ini adalah analisis deskriptif yang bersifat mendeskripsikan suatu keadaan maupun kondisi secara ilmiah (Masyhud, 2010). Melalui analisis kesalahan menggunakan teori kesalahan Watson, kesalahan siswa dalam menjawab persoalan integral tak tentu dapat diketahui dan dikelompokkan untuk kemudian dipaparkan secara deskriptif. Subjek penelitian merupakan siswa-siswi kelas XI.IPA.1 SMA Negeri 2 Tanjungpinang pada semester genap tahun ajaran 2015/2016 yang berjumlah 39 siswa. Pada saat penelitian terdapat 9 dari 39 siswa yang tidak hadir dan tidak ikut serta dalam tes. Topik Pembelajaran adalah Integral Tak Tentu dengan Metode Subsitusi. Berdasarkan informasi yang diperoleh dari guru matematika kelas XI.IPA.1, kemampuan yang dimiliki siswa yang berada didalam kelas ini terbilang heterogen (berbeda). Ada siswa yang pintar dan ada yang kurang dalam prestasi akademiknya. Situasi saat pelaksanaan penelitian ini yaitu tahap evaluasi terhadap topik pembelajaran integral tak tentu dengan metode subsitusi sudah cukup bagus.

Instrumen penelitian berupa lembar soal tes yang memuat soal essay yang terdiri dari 2 paket, yaitu paket A dan paket B. Masing-masing paket memuat 8 butir soal. Pada setiap paket mempunyai tipe soal yang sama/homogen namun hanya dibedakan pada bilangan yang digunakan. Soal tes yang diberikan memuat topik integral tak tentu menggunakan metode subtitusi. Soal pada tes tertulis ini hanya memuat integral fungsi aljabar dan fungsi trigonometri. Dengan fungsi aljabar sebanyak 6 soal dan fungsi trigonometri sebanyak 2 soal. Tujuan dari pemberian tes ini adalah untuk mengevaluasi sejauh mana pemahaman siswa tentang topik integral tak 
Nurhikmah, S., \& Febrian, F. (2016). ANALISIS KESALAHAN SISWA DALAM MENYELESAIKAN PERMASALAHAN INTEGRAL TAK TENTU. JURNAL TATSQIF, 14(2). Retrieved from http://ejurnal.iainmataram.ac.id/index.php/tatsqif/article/view/1074

tentu dan untuk mengetahui kesalahan apa saja yang banyak dilakukan oleh siswa dalam menjawab soal tentang topik ini.

Instrumen penelitian juga dinamakan alat pengumpul data yang diperoleh dengan mengumpulan lembar jawaban hasil kerja siswa setelah tes selesai dilaksanakan. Selanjutnya dari lembar jawaban siswa dianalisis dengan bertumpu pada kategori kesalahan menurut Watson. Pengkategorian kesalahan siswa berdasarkan teori kesalahan menurut Watson yang kemudian setiap tipe kesalahan disimbolkan dengan K1, K2, K3, K4, K5, K6, dan K7. Dengan keterangan setiap tipe kesalahan sebagai berikut:

K1: Masalah hierarki keterampilan, kesalahan yang dikategorikan dalam masalah hierarki keterampilan jika terdapat jawaban siswa yang salah dalam perhitungan.

K2: Prosedur tidak tepat, kesalahan yang dikategorikan yaitu jika terdapat jawaban siswa yang tidak sesuai dengan rumus atau aturan yang berlaku dalam matematika.

K3: Manipulasi tidak langsung, kesalahan yang dapat dikategorikan yaitu jika terdapat penyelesaian soal siswa yang tidak logis.

K4: Data tidak tepat, kesalahan yang dapat dikategorikan yaitu jika terdapat penyelesaian soal tes yang salah ataupun salah dalam memasukkan data dalam variabel.

K5: Data hilang, kesalahan yang dapat dikategorikan yaitu jika terdapat data dalam penyelesaian soal tidak sama dengan data pada soal ataupun mendapatkan hasil pada penyelesaian tetapi tidak memiliki proses untuk mendapatkan hasil tersebut.

K6: Kesimpulan hilang, kesalahan yang dikategorikan dalam kesimpulan hilang jika terdapat jawaban siswa yang tidak mempunyai hasil akhir.

K7: Konflik level respon, kesalahan yang dikategorikan dalam konflik level respon jika terdapat dua cara penyelesaian dan hasil yang berbeda. 
Analisis pertama dimulai dari paket A. Setiap anggota kelompok menganalisis 2 atau 3 lembar jawaban siswa yang merupakan soal paket A dan selanjutnya dianalisis bersama. Dalam proses menganalisis jawaban siswa dilakukan diskusi untuk mengkategorisasikan suatu kesalahan menurut teori Watson, dan setiap kertas jawaban yang telah dianalisis oleh satu anggota kelompok akan dilakukan pergantian penganalisisan dengan anggota lainnya untuk menghindari subjektifitas agar penganalisisan dapat bersifat lebih objektif. Selain itu setiap anggota menyampaikan jika ada kendala dalam penentuan kategori kesalahan yang terjadi pada hasil kerja siswa.

Setelah selesai menganalisis soal paket A, analisis dilanjutkan pada soal paket B. Setiap anggota juga menganalisis satu persatu lembar jawaban siswa seperti penganalisisan pada paket A dan kemudian didiskusikan kembali dalam kelompok. Kemudian hasil analisis tersebut disajikan dalam bentuk tabel dan kemudian dihitung persentase kesalahan per butir soal dan jenis kesalahan secara keseluruhan. Selanjutnya, disimpulkan kesalahan yang dominan terjadi pada siswa atau bahkan tidak adanya jawaban sama sekali oleh siswa pada nomor soal yang bersangkutan.

\section{TEMUAN DAN PEMBAHASAN}

Berdasarkan hasil analisis lembar jawaban siswa yang telah dilakukan, diperoleh data yang disajikan dalam tabel berikut: 


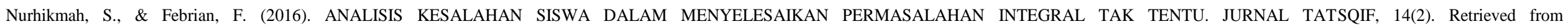
http://ejurnal.iainmataram.ac.id/index.php/tatsqif/article/view/1074

Tabel 1

Tabel Analisis Kesalahan Siswa Dalam Menjawab Soal Test Tentang Integral

\begin{tabular}{|c|c|c|c|c|c|c|c|c|c|c|c|c|c|c|c|c|c|c|c|c|c|c|c|c|c|c|c|c|c|c|c|c|}
\hline & & \multicolumn{15}{|c|}{ Nama Siswa Soal A } & \multicolumn{15}{|c|}{ Nama Siswa Soal B } & \\
\hline $\begin{array}{l}z \\
0 \\
0 \\
0 \\
0 \\
0 \\
0 \\
0\end{array}$ & 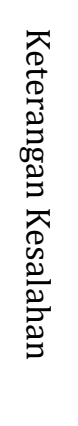 & 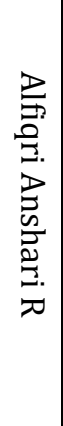 & 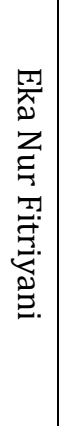 & 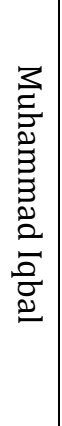 & 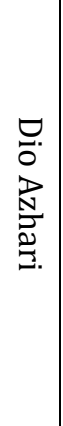 & 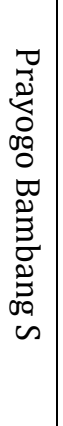 & 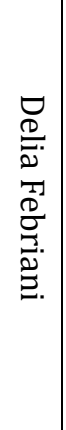 & 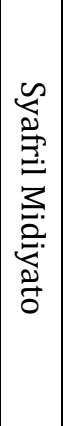 & 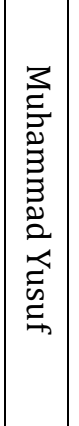 & 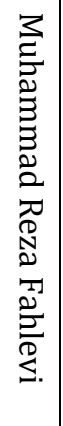 & 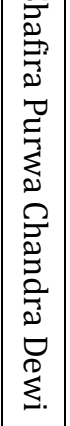 & 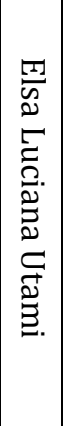 & 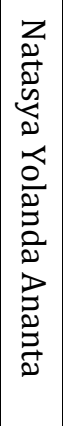 & 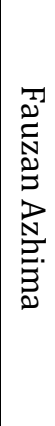 & 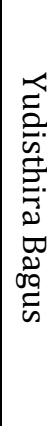 & 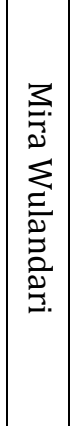 & 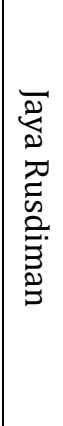 & 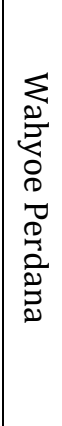 & 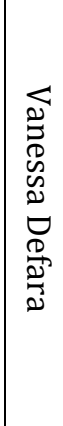 & 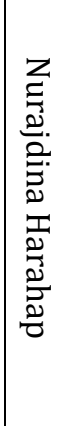 & 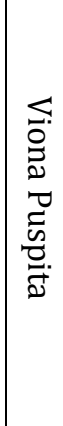 & 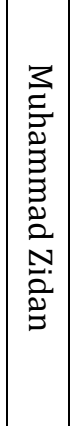 & 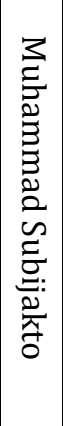 & 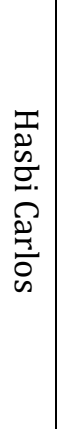 & 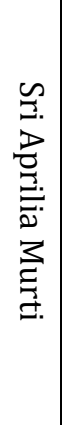 & 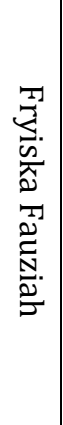 & 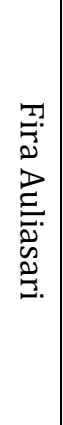 & 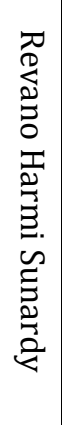 & 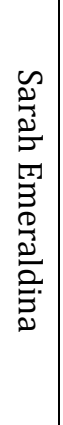 & $\begin{array}{l}\underset{D}{D} \\
\underset{\mathcal{D}}{0}\end{array}$ & & \\
\hline \multirow{7}{*}{1} & K1 & & & & & & & & & & & & & & & & & & $\sqrt{ }$ & & $\sqrt{ }$ & & & & & & & & & & & 2 \\
\hline & $\mathrm{K} 2$ & & $\sqrt{ }$ & $\sqrt{ }$ & & & & & & $\sqrt{ }$ & & & & & & & $\sqrt{ }$ & & & $\sqrt{ }$ & $\sqrt{ }$ & & & & $\sqrt{ }$ & & & & & $\sqrt{ }$ & & 8 \\
\hline & K3 & $\sqrt{ }$ & & & & & & & & & & & & & & & $\sqrt{ }$ & & & $\sqrt{ }$ & & & & & & & & & & & & 3 \\
\hline & K4 & & $\sqrt{ }$ & $\sqrt{ }$ & & $\sqrt{ }$ & & $\sqrt{ }$ & & & & & & $\sqrt{ }$ & & & & & & & & & & & & & & & & & & 5 \\
\hline & K5 & & & & & & & & & & & & & & $\sqrt{ }$ & & & $\sqrt{ }$ & $\sqrt{ }$ & & & & & & & $\sqrt{ }$ & & & & & & 4 \\
\hline & K6 & & & & & & & & $\sqrt{ }$ & $\sqrt{ }$ & & $\sqrt{ }$ & & & & & & $\sqrt{ }$ & & & & & & & & & & & & & & 4 \\
\hline & K7 & & & & & & & & & & & & & & & & & & & & $\sqrt{ }$ & & & & & & & & & & & 1 \\
\hline \multicolumn{32}{|c|}{ Jumlah Seluruh Kesalahan pada soal nomor 1} & $\begin{array}{l}2 \\
7\end{array}$ \\
\hline \multirow{6}{*}{2} & K1 & & & & & & & & & $\sqrt{ }$ & & & & & & & & & & & & & & & & & & & & & & 1 \\
\hline & K2 & & & & & & & & & $\sqrt{ }$ & & & & & & & & & & & & & & & & & & & $\sqrt{ }$ & & & 2 \\
\hline & K3 & & & & & & & & & $\sqrt{ }$ & & & & & & & & & $\sqrt{ }$ & & & & & & & & & & & & & 2 \\
\hline & K4 & & $\sqrt{ }$ & & & & & & & & $\sqrt{ }$ & & & $\sqrt{ }$ & $\sqrt{ }$ & & & & & & & & & & & & & & & & & 4 \\
\hline & K5 & & & & $\sqrt{ }$ & $\sqrt{ }$ & & & & & & & & & & & & & $\sqrt{ }$ & & & & & & & $\sqrt{ }$ & & $\sqrt{ }$ & & & & 5 \\
\hline & K6 & & & & & & & & & & & & & & & & & & & & & & & & & $\sqrt{ }$ & & & & & & 1 \\
\hline
\end{tabular}




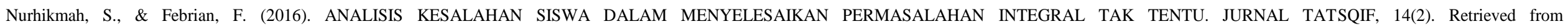
http://ejurnal.iainmataram.ac.id/index.php/tatsqif/article/view/1074
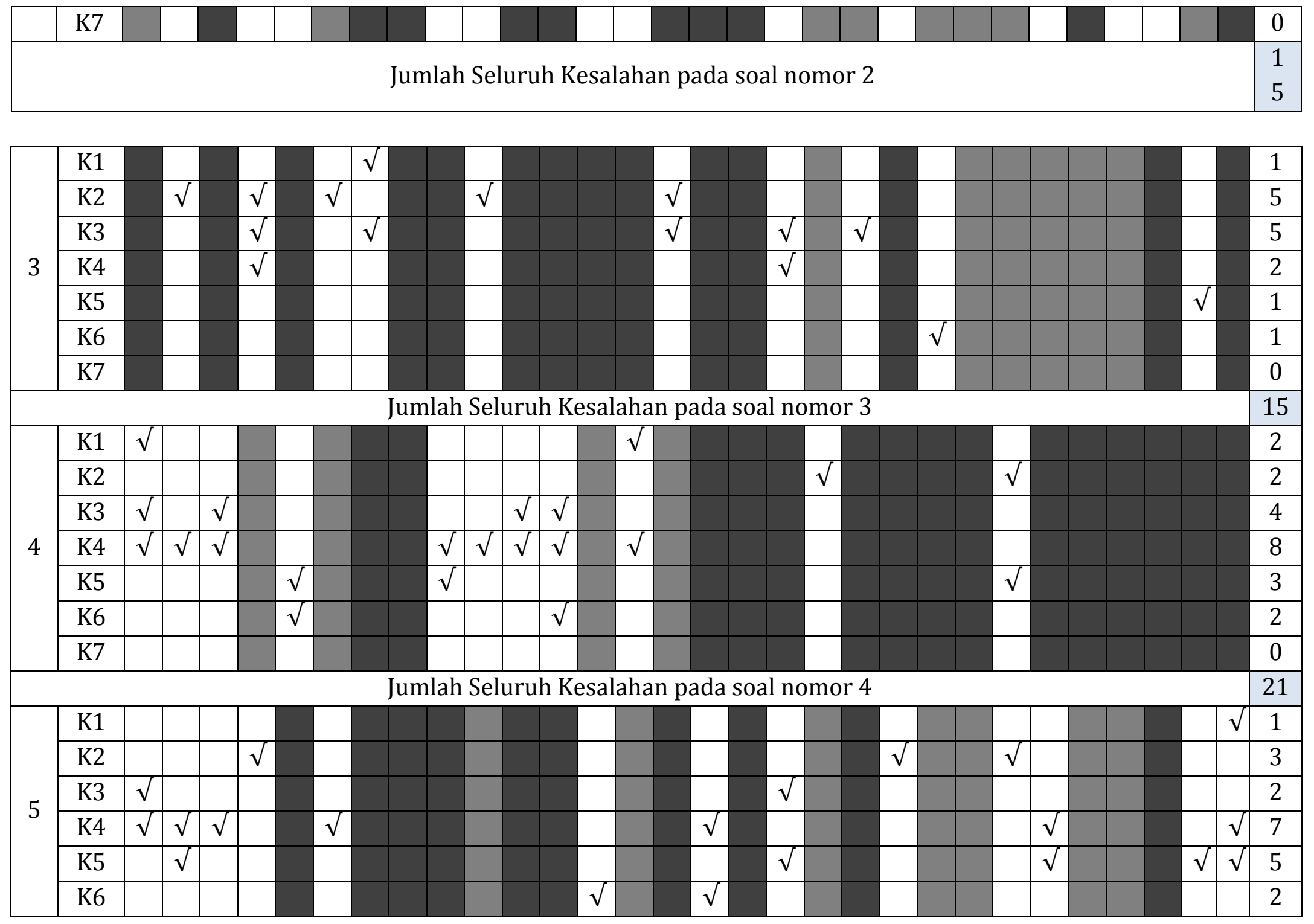


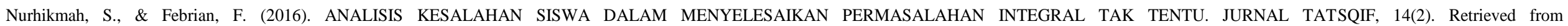
http://ejurnal.iainmataram.ac.id/index.php/tatsqif/article/view/1074

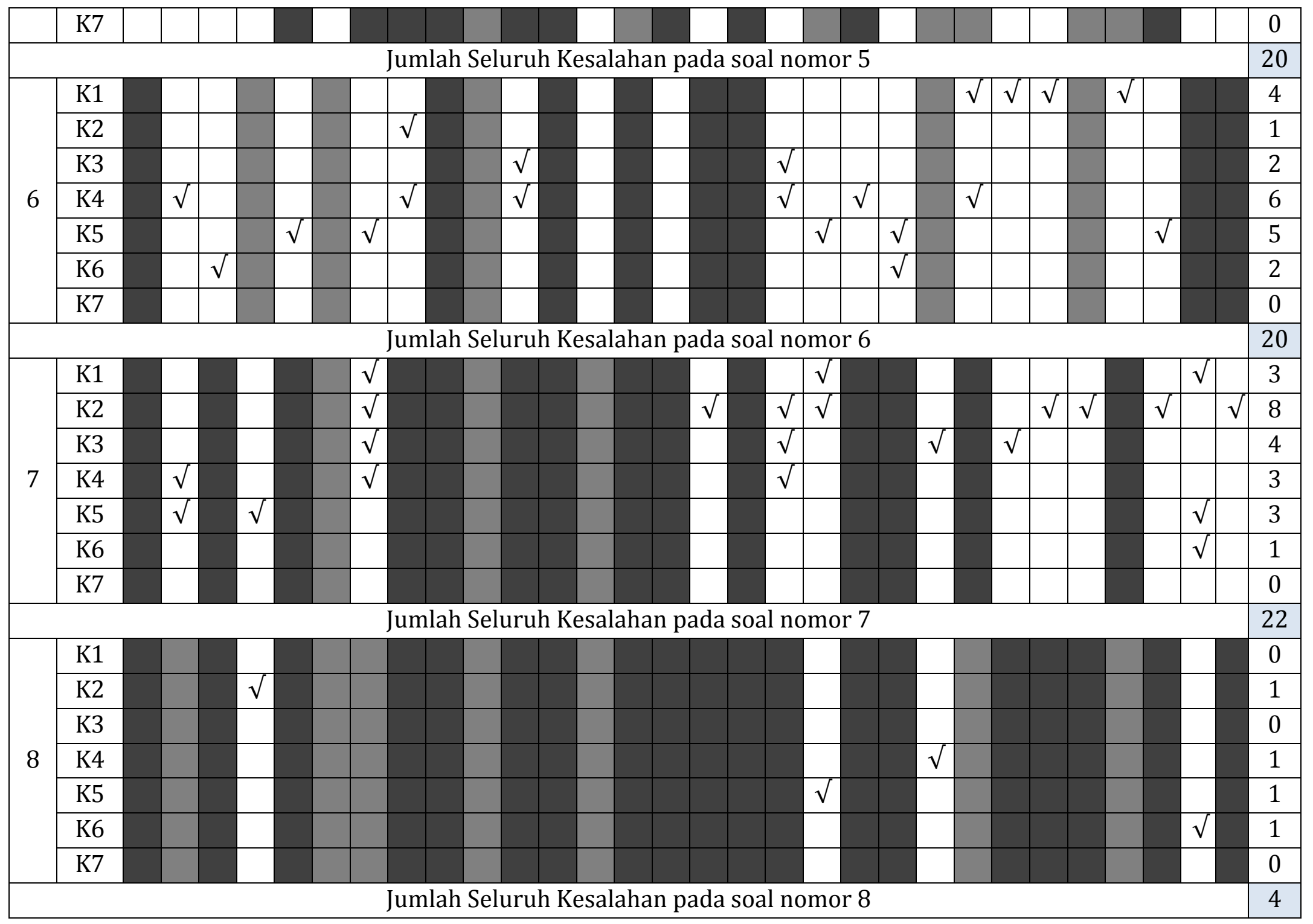




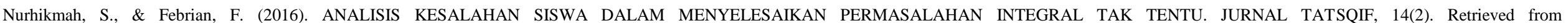
http://ejurnal.iainmataram.ac.id/index.php/tatsqif/article/view/1074

\begin{tabular}{l|l|c|}
\hline & & 14 \\
& & Jumlah Semua Kesalahan \\
\hline
\end{tabular}


Persentase jumlah kesalahan siswa yang terjadi pada setiap soal menggunakan rumus :

$$
P=\frac{n}{N} \times 100 \%
$$

Keterangan :

$P=$ Persentase masing-masing jenis kesalahan siswa

$n=$ Jumlah kesalahan pada setiap jenis kesalahan

$N=$ Jumlah seluruh kesalahan pada semua butir soal.

Hasil persentase tiap jenis kesalahan siswa yang diperoleh dari hasil analisis adalah :

Tabel 2

Persentase Banyaknya Kesalahan Siswa Secara Keseluruhan

\begin{tabular}{|c|c|c|c|c|c|c|c|c|c|}
\hline & SOAL & SOAL & SOAL & SOAL & SOAL & SOAL & SOAL & SOAL & TOTAL \\
& 1 & 2 & 3 & 4 & 5 & 6 & 7 & 8 & $\%$ \\
\cline { 2 - 9 } & $\%$ & $\%$ & $\%$ & $\%$ & $\%$ & $\%$ & $\%$ & $\%$ & \\
\hline K1 & 7,40 & 6,66 & 6,66 & 9,52 & 5 & 20 & 13,63 & 0 & 9,72 \\
\hline K2 & 29,62 & 13,33 & 33,33 & 9,52 & 15 & 5 & 36,36 & 25 & 20,83 \\
\hline K3 & 11,11 & 13,33 & 33,33 & 19,04 & 10 & 10 & 18,18 & 0 & 15,28 \\
\hline K4 & 18,51 & 26,66 & 13,33 & 38,09 & 35 & 30 & 13,63 & 25 & 25 \\
\hline K5 & 14,81 & 33,33 & 6,66 & 14,28 & 25 & 25 & 13,63 & 25 & 18,57 \\
\hline K6 & 14,81 & 6,66 & 6,66 & 9,52 & 10 & 10 & 4,54 & 25 & 9,72 \\
\hline K7 & 3,70 & 0 & 0 & 0 & 0 & 0 & 0 & 0 & 0,69 \\
\hline
\end{tabular}

Hasil analisis data menunjukkan persentase pada kesalahan masalah hierarki keterampilan sebesar 9,72\%. Kesalahan ini banyak terjadi pada soal nomor 6 dan nomor 7. Pada soal nomor 6 kesalahan hierarki keterampilan sebesar 20\%. Contoh kesalahan siswa pada nomor ini adalah adanya eror kalkulasi yang dilakukan siswa pada operasi pembagian yaitu $\frac{6 z}{2 z}$ yang seharusnya hasilnya adalah 3 tetapi siswa menuliskan 3z. Sedangkan pada soal nomor 7 sebesar 13,63\%. Kesalahan yang dilakukan siswa pada soal nomor 7 adalah kurang teliti dan salah dalam melakukan pengoperasian dalam menghitung. 
Persentase kesalahan prosedur tidak tepat sebesar 20,83\%. Kesalahan ini sering terjadi pada soal nomor 3 dan nomor 7. Pada soal nomor 3 kesalahan prosedur tidak tepat sebesar 15\%. Contoh kesalahan dapat dilihat pada lembar kerja siswa sebagai berikut:

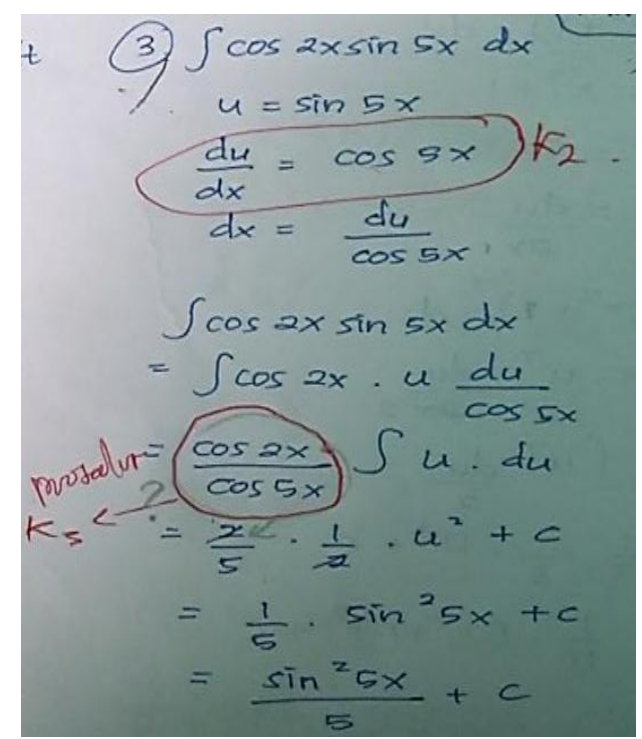

Gambar 1

Prosedur Tidak Tepat/ Miskonsepsi (Jawaban tertulis siswa)

Berdasarkan gambar 1 diatas, dapat dilihat kesalahan siswa yang salah dalam menggunakan konsep turunan trigonometri. Dimana seharusnya hasil turunan dari $\sin 5 x$ adalah $5 \cos 5 x$. Sedangkan pada soal nomor 7 kesalahan prosedur tidak tepat sebesar 36,36\%. Contoh kesalahan yang dilakukan siswa pada soal nomor ini adalah siswa mencoba mengkalikan $\cos x$ dengan 2 agar menghasilkan $\cos 2 x$, dimana proses perkalian yang dilakukan tidak sesuai dengan kaidah yang berlaku.

Persentase kesalahan manipulasi tidak langsung sebesar 15,28\%. Kesalahan ini sering terjadi pada soal nomor 3 dan nomor 4. Pada soal nomor 3 sebesar 33,33\%. Sedangkan pada soal nomor 4 sebesar 19,04\%. Contoh kesalahan siswa pada nomor 4 dapat dilihat pada gambar berikut: 


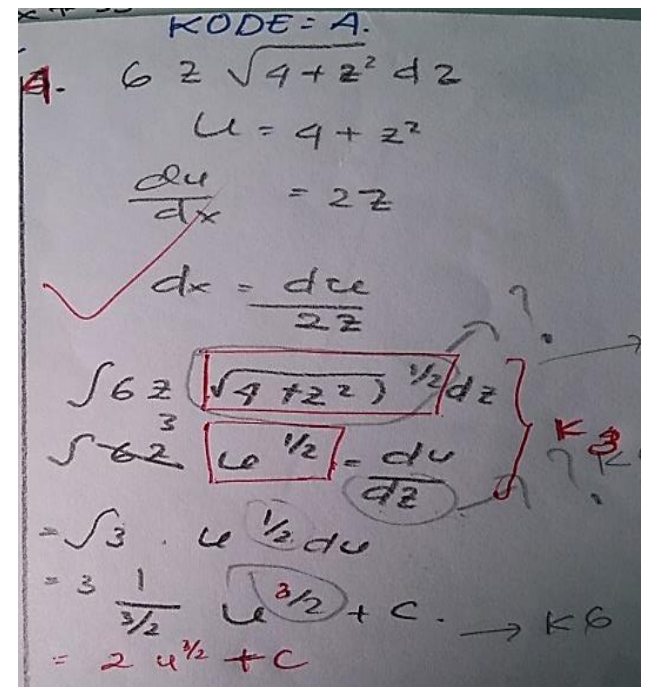

Gambar 2

Manipulasi Tidak Langsung (Jawaban tertulis siswa)

Berdasarkan gambar 2 diatas, terlihat siswa memangkatkan $\sqrt{4+z^{2}}$ dengan $\frac{1}{2}$ padahal sesuai aturan yang berlaku penulisan yang benar adalah $\left(4+z^{2}\right)^{\frac{1}{2}}$.

Persentase kesalahan data tidak tepat sebesar 25\%. Kesalahan ini sering terjadi pada soal nomor 4 dan nomor 5. Pada soal nomor 4 kesalahan data tidak tepat sebesar 38,09\%. Contoh kesalahan siswa pada nomor ini adalah adanya salah penulisan data yang ditulis siswa. Siswa mengganti angka 4 yang ada pada soal menjadi angka 6 dan penulisan $d u$ setelah pengintegralan. Sedangkan pada soal nomor 5, kesalahan data tidak tepat sebesar 35\%. Kesalahan yang dilakukan siswa pada soal nomor ini adalah kurangnya data yang dimasukkan dari pengoperasian sebelumnya.

Persentase kesalahan data hilang sebesar 18,75\%. Kesalahan ini sering terjadi pada soal nomor 5 sebesar 33,33\%. Kesalahan siswa pada kategori ini adalah adanya data yang hilang pada saat menginputkan data, sehingga membuat siswa bingung untuk melanjutkan proses penyelesaian tersebut. Contohnya adalah pada soal tertera $3 x^{2}-3 x+5$ namun siswa membuat permisalan $u=3 x^{2}-3 x$ padahal +5 seharusnya ikut disertakan pada permisalan $u$ tersebut. 
Persentase kesalahan kesimpulan hilang sebesar 9,72\%. Kesalahan ini sering terjadi pada soal nomor 1 sebesar 14,81\% dan 8 sebesar 25\%. Contoh kesalahan kesimpulan hilang yang dilakukan siswa dapat dilihat pada gambar berikut:

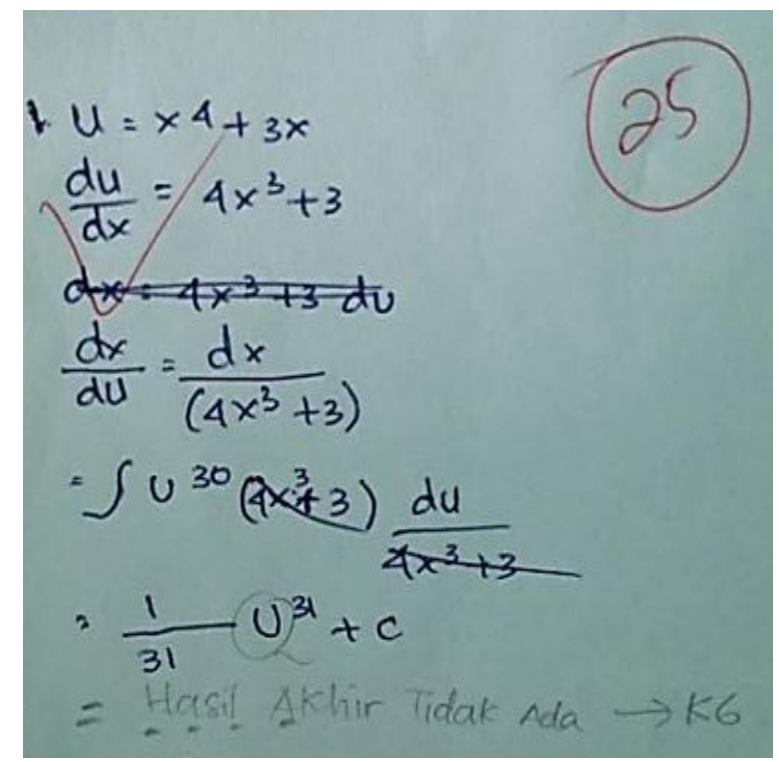

\section{Gambar 3}

Kesimpulan Hilang (Jawaban tertulis siswa)

Berdasarkan gambar, penyebab siswa sering melakukan kesalahan kesimpulan hilang adalah siswa lupa dalam menuliskan hasil akhir dari proses yang telah dilakukan dan juga tidak tuntasnya proses penyelesaian soal.

Persentase kesalahan konflik level respon sebesar 0,69\%. Kesalahan ini merupakan kesalahan paling sedikit yang dilakukan siswa. Kesalahan konflik level respon ini hanya terjadi pada soal nomor 1 sebesar 3,70\%. Kesalahan siswa pada soal nomor ini adalah siswa kurang memahami maksud dari soal sehingga penyelesaian soal menjadi tidak maksimal.

Berdasarkan hasil analisis, dapat disimpulkan bahwa persentase dominan kesalahan yang dilakukan siswa pada soal tentang topik integral tak tentu adalah data tidak tepat (K4) yaitu sebesar $25 \%$. 


\section{SIMPULAN}

Berdasarkan hasil dan pembahasan dari data yang diperoleh dapat disimpulkan sebagai berikut :

1. Persentase dominan kesalahan dari setiap jenis kesalahan pada setiap nomor soal sebagai berikut:

a) Dominan kesalahan pada soal nomor 1 adalah prosedur tidak tepat (K2) sebesar 29,62\%.

b) Dominan kesalahan pada soal nomor 2 adalah data hilang (K5) sebesar $33,33 \%$.

c) Dominan kesalahan pada soal nomor 3 adalah prosedur tidak tepat (K2) dan manipulasi tidak langsung (K3) sebesar 33,33\%.

d) Dominan kesalahan pada soal nomor 4 adalah data tidak tepat (K4) sebesar 38,09\%.

e) Dominan kesalahan pada soal nomor 5 adalah data tidak tepat (K4) sebesar $35 \%$.

f) Dominan kesalahan pada soal nomor 6 adalah data tidak tepat (K4) sebesar $30 \%$.

g) Dominan kesalahan pada soal nomor 7 adalah prosedur tidak tepat (K2) sebesar 36,36\%.

h) Dominan kesalahan pada soal nomor 8 adalah prosedur tidak tepat (K2), data tidak tepat (K4), data hilang (K5), dan kesimpulan hilang (K6) sebesar $25 \%$.

2. Persentase kesalahan dari setiap jenis kesalahan dari seluruh butir soal sebagai berikut:

a) Masalah hierarki keterampilan (K1) sebesar 9,72\%.

b) Prosedur tidak tepat (K2) sebesar 20,83\%.

c) Manipulasi tidak langsung (K3) sebesar 15,28\%.

d) Data tidak tepat (K4) sebesar $25 \%$

e) Data hilang (K5)sebesar 18,75\%.

f) Kesimpulan hilang (K6) sebesar 9,72\%. 
g) Konflik level respon (K7) sebesar 0,69\%.

h) selain dari ketujuh kesalahan diatas sebesar $0 \%$.

3. Jenis kesalahan yang paling dominan kesalahan siswa secara keseluruhan dari 8 soal tes adalah data tidak tepat (K4), yaitu sebesar $25 \%$.

\section{UCAPAN TERIMA KASIH}

Ucapan terimakasih penulis kepada kepala sekolah, guru Matematika, dan siswa kelas XI.IPA.1 SMA Negeri 2, Tanjungpinang serta kepada Dosen Pendidikan Matematika, Febrian, S.Pd., M.Sc, yang telah membimbing pelaksanaan studi analisis kesalahan dan penulisan artikel imliah ini. Kemudian rekan-rekan penaganalisis, mahasiswa Pendidikan Matematika FKIP Universitas Maritim Raja Ali Haji yang turut membantu perencanaan, pelaksanaan, dan penulisan.

\section{REFERENSI}

Abdul Halim Fathani. (2009). Matematika Hakikat dan Logika. Yogyakarta: Ar-Ruzz Media.

Arifin, Zainal. (2014). Evaluasi Pembelajaran. Bandung: Remaja Rosdakarya Arikunto, Suharsimi. (2012). Dasar-dasar Evaluasi. Jakarta: Bumi Aksara Depdiknas. (2004). Kurikulum 2004 Standar Kompetensi Mata Pelajaran Matematika Sekolah Menengah Atas dan Madrasah Aliyah. Jakarta: Depdiknas.

Febriana Nilasari, Triana., dkk. (2015). Analisis Kesalahan Siswa Berdasarkan Kategori Kesalahan Watson Dalam Menyelesaikan Soal-Soal Himpunan Di kelas VII D SMP Negeri 11 Jember. Artikel Ilmiah Mahasiswa PMIPA. Jember: FKIP Universitas Jember (UNEJ). 
http://repository.unej.ac.id/bitstream/handle/123456789/64146/TRISTIA N\%20FEBRIANA\%20NILASARI.pdf?sequence=1. Di Akses pada tanggal 11 Juni 2016.

Nitko, Anthony J. (1996). Educational Assessment of Students, Second Edition. Ohio: Merrill an imprint of Prentice Hall Englewood Cliffs.

Sulthon Masyhud, M. (2012). Metode Penelitian Pendidikan Edisi 3, Cetakan ke 1. Jember: Lembaga Pengembangan Manajemen dan Profesi Kependidikan (LPMPK)

Sunardi. (1995). Analisis Kesalahan Siswa dalam Menyelesaikan Soal Geometri Analitika Ruang Berdasarkan Taksonomi SOLO. Jember: Lembaga Penelitian Universitas Jember.

Uno, H. B. (2009). Model Pembelajaran (cetakan IV). Jakarta: Bumi Aksara.

Verberg, Dale dan Erwin J. Purcell. (2010). Kalkulus. Tanggerang: Binapura Aksara Publisher. 